\title{
PENERAPAN MODEL PEMBELAJARAN KONTEKSTUAL BERBASIS MODELING UNTUK MENINGKATKAN AKTIVITAS DAN HASIL BELAJAR SISWA KELAS VII.1 PADA MATA PELAJARAN PKN DI SMP NEGERI 3 MATARAM TAHUN PELAJARAN 2012/2013
}

\author{
H. M. YUNAN \& SUSILAWATI \\ (Dosen PNS Dpk Kopertis VIII)
}

\begin{tabular}{l} 
INFO ARTIKEL \\
Riwayat Artikel: \\
Diterima: $06-09-2016$ \\
Disetujui: 30-09-2016 \\
\hline Kata Kunci: \\
Model \\
pembelajarankontekstu, \\
aktivitas belajar, hasil \\
belajar.
\end{tabular}

\section{A. LATAR BELAKANG}

Pendidikan merupakan suatu kebutuhan pokok bagi suatu bangsa yang mengandung kewajiban moral atas harkat dan martabat manusia Indonesia, pendidikan yang menjadi amanat konstitusi yang tercantum secara mendasar didalam pembukaan Undang-Undang Dasar 1945. Tujuan nasional antara lain disebutkan bahwa pemerintahan Indonesia bertujuan untuk mencerdaskan kehidupan bangsa, untuk merealisasikan tujuan tersebut, maka perlu adanya acuan tentang sistem pendidikan.

\begin{abstract}
Abstrak: Model pembelajaran merupakan salah satu cara yang digunakan dalam menyampaikan materi pembelajaran. Salah satu model pembelajaran yang digunakan dalam penelitian ini adalah model pembelajaran kontekstual berbasis modeling yaitu proses pembelajarandengan memperagakan guru sebagai model yang dapat ditiru oleh setiap siswa, orang berpengalaman dalam menyampaikan suatu materi pembelajaran Pendidikan Pancasila dan Kewarganegaraan (PKn) dapat dikaitkandengan modelnya. Penelitian ini berdasarkan permasalahan: Apakah dengan penerapan model pembelajaran kontekstual berbasis modeling pada mata pelajaran PKn di kelas VII.1 SMP Negeri 3 Mataram tahun pelajaran 2012/2013 dapat meningkatkan aktivitas dan hasil belajar siswa sedangkan tujuan penelitian adalah untuk mengetahui penerapan model pembelajaran kontekstual berbasis modeling terhadap peningkatan aktivitas dan hasil belajar siswa. Sedangkan manfaat penelitian ini akan memberikan sumbangan yang baik pada sekolah itu sendiri dalam rangka memperbaiki dan meningkatkan proses belajar mengajar khususnya dan sekolah pada umumnya.

Metode yang digunakan dalam penelitian ini adalah metode eksprimen dengan pendekatandiskriptif kuantitatif karena data yang diinginkan berupa data diskriptif atau pemaparan dari suatu peristiwa, kegiatan atau fakta yang diteliti dengan desainpre-test dan post-test. Desain ini digunakan sebelum eksprimen dan setelah eksprimen. Yang menjadi populasi dalam penelitian ini adalah siswa kelas VII.1 yang berjumlah 27 orang pada SMP Negeri 3 Mataram. Jenis data yang digunakan adalah kuantitatif dengan sumber data primer dans ekunder. Sedangkan analisis yang digunakan adalah analisis statistic dengan rumus TTes sebagai berikut:

$$
t=\frac{\mathrm{N} d}{\sqrt{\frac{\mathrm{DN}}{\mathrm{N}(\mathrm{N}-1)}}}
$$

Hasil penelitian menunjukkan bahwa t-hitung sebesar $6.48>$ dari t-tabel 1.706 yang berarti terdapat pengaruh yang signifikan dengan penggunaan metode modeling terhadap aktivitas dan hasil belajar siswa. Rata-rata hasil belajar siswa yang tidak dikenakan perlakuan sebesar 82.22 dan hasil belajar siswa yang dikenakan perlakuan sebesar 64.44, sedangkan ketuntasan belajar siswa yang menggunakan metode pembelajaran modeling 92.59\% dan ketuntasan belajar siswa yang tidak dikenakan metode pembelajaran modeling sebesar $44.44 \%$. dengan melihat hasil penelitian di atas dapat disimpulkan bahwa penerapan model pembelajaran kontekstual berbasis modeling dapat meningkatkan aktivitas dan hasil belajar siswa kelas VII.1 pada mata pelajaran PKn di SMP Negeri 3 Mataram, tahun pelajaran 2012/2013.
\end{abstract}

Hasil belajar masih dipandang kurang baik sebagian besar siswa belum mampu menggapai potensi ideal atau optimal yang dimilikinya. Oleh karena itu perlu adanya suatu perubahan proses pembelajaran dari kebiasaan yang sudah berlangsung selama ini.Pembelajaran yang selama ini dikembangkan dan banyak dikenal keseluruh pelosok tanah air adalah pembelajaran Aktif, Kraetif, Efektif, dan Menyenangkan atau disingkat dengan PAKEM. Disebut demikian karena pembelajaran ini dirancang agar mengaktifkan anak, mengembangkan kreativitas sehingga efektifnamun tetap menyenangkan. 
Didalam Undang-Undang Sisdiknas Tahun 2003 tersebut jelas dicantumkan bahwa sistem pendidikan nasional harus melaksanakan fungsinya yaitu meningkatkan keimanan dan ketaqwaan kepada Tuhan Yang Maha Esa serta akhlak mulia dalam rangka mencerdaskan kehidupan bangsa. Proses belajar mengajar adalah suatu aspek dari lingkungan sekolah yang di organisasikan.)

Untuk meningkatkan mutu yang diharapkan, sekarang ini pemerintah menerapkan Kurikulum Tingkat Satuan Pendidikan (KTSP) yang didalamnya diperkenalkan salah satu istilah yang sekarang ini lagi tern digunakan dalam kegiatan pembelajaraan yakni model pembelajaran kontekstual CTL (Mulyasa, 2002:5). Istilah ini jika dikasih lebih lanjut, maka pada dasarnya tidak jauh beda dengan apa yang sudah diterapkan dalam pendekatan keterampilan proses pembelajaran sebelumnya. Hanya saja proses keterampilan yang diterapkan dalam proses pembelajaran tidak selalu dapat dilakukan, karena hanya dapat dilaksanakan atau diterapkan pada pelajaran tertentu saja.

Pembelajaran dan pengajaran kontekstual melibatkan para siswa dalam aktivitas penting yang membantu mereka mengaitkan pelajaran akademis dengan konteks kehidupan nyata yang mereka hadapi. Dengan mengaitkan keduanya, para siswa melihat makna di dalam tugas sekolah. Ketika para siswa menyusun proyek atau menemukan permasalahan yang menarik, ketika mereka membuat pilihan dan menerima tanggung jawab, mencari informasi dan menarik kesimpulan, ketika mereka secara aktif memilih, menyusun, mengatur, menyentuh, merencanakan, menyelidiki, mempertanyakan, dan membuat keputusan, mereka mengaitkan isi akademis dengan konteks dalam situasi kehidupan, dan dengan cara ini mereka menemukan makna. Penemuan makna adalah ciri utama dari CTL. (Johnson Elaine, 2002: 35)

Pelaksanaan proses pembelajaran Pendidikan Pancasiladan Kewarganegaraan (PKn) di Sekolah Menengah Pertama (SMP) tergantung pada guru, bahkan dapat dikatakan berhasil tidaknya pembelajaran Pendidikan Pancasila dan Kewarganegaraan (PKn). Khususnya pendidikan pada umumnya sangat ditentukan oleh aktivitas tenaga edukatif yang Profesional, Efektif dan Kreatif, serta unsur terkait lainnya. Hal ini diartinya bahwa setiap guru yang memberikan pelajaran pada Sekolah Menengah Pertama (SMP), hendaknya berusaha melakukan intropeksi diri dari berbagai sudut pandang, sehingga benar-benar dapat menunjang pencapaian hasil pendidikan dan pembelajaran yang baik.

Untuk ditemukan sebuah strategi belajar mengajar CTL yang merupakan konsep belajar yang membantu guru mengaitkan antara materi yang diajarkan dengan situasi dunia nyata dan mendorong siswa untuk membuat hubungan antara pengetahuan yang dimiliki sebelumnya. Metode pembelajaran kontekstual merupakan strategi mengajar yang lebih memberdayakan siswa dalam belajar sehingga anakanak akan lebih aktif, mandiri, dan kritis dalam bidangnya.

Dalam kaitannya dengan model pembelajaran kontekstual (CTL) berbasismodeling, peneliti tertarik untuk meneliti penerapannya dalam proses belajar mengajar pada mata pelajaran Pendidikan Pancasila dan Kewarganegaraan (PKn) di SMPN 3 Mataram, karena telah menerapkan Kurikulum Satuan Pendidikan (KTSP). Dan untuk menekankan siswa untuk dapat meningkatkan aktivitas dan hasil belajarnya maka model pembelajaran kontekstual berbasismodeling ini dipergunakan oleh pendidik agar dapat melibatkan siswa dalam proses pembelajaran dan siswa tidak hanya mendengarkan saja materi yang disampaikan oleh guru.

Model pembelajaran permodelan atau modeling adalah proses pembelajaran dengan memperagakan suatu contoh yang dapat ditiru oleh siswa. (Sugiyanto,2010: 20). Dengan contoh guru dapat memperagakan salah satu materi pembelajaran yang sedang disampaikannya supaya siswa dapat meningkatkan aktivitas dan hasil belajarnya, bahkan dalam model pembelajaran modeling ini tidak hanya guru yang dapat dijadikan model tetapi siswa dan bisa juga orang lain dari luar yang sengaja diundang untuk dapat diikutsertakan menjadi model peraga di dalam proses belajar mengajar.

Berdasarkan observasi yang dilakukan oleh peneliti pada SMPNegeri 3 Mataram di kelas VII.1, hasil belajar siswa pada mata pelajaran PKn belum memenuhi standar atau belum maksimal, hal ini dibuktikan dari nilai-nilai siswa yang sebelumnya dan nilai raport siswa yang dibawah nilai rata-rata atau dibawah standar ketuntasan klaksikal belajar (KKM). Oleh karena itu diperlukan model pembelajaran kontekstual yang menekankan hasil belajar siswa kepada proses keterlibatan siswa secara penuh untuk dapat menemukan materi yang akan dipelajari dan menghubungkan dengan situasi kehidupan nyata sehingga mendorong siswa untuk dapat menerapkan dalam kehidupan mereka. Dengan dasar inilah peneliti tertarik untuk mengadakan penelitian tentang "Penerapan Model Pembelajaran Kontekstual BerbasisModeling Untuk Meningkatkan Aktivitas dan Hasil Belajar Siswa Kelas VII.1 Pada Mata Pelajaran Pendidikan Pancasila Kewarganegaraan (PKn) di SMPN 3 Mataram, Tahun Pelajaran 2012/2013".

\section{B. METODE PENELITIAN}

\section{METODE YANG DIGUNAKAN}

Metode penelitian adalah sebagai cara ilmiah untuk mendapatkan data yang valid dengan tujuan dapat ditemukan, dikembangkan, dan dibuktikan, sehingga pada gilirannya dapat digunakan untuk memahami, memecahkan, dan mengantisipasi masalah dalam bidang penelitian. Secara umum metode ada dua metode kuantitatif dan kualitatif. Metode kuantitatif dapat diartikan sebagaimetode penelitian yang berlandaskan pada filsafat positivisme, digunakan untuk meneliti pada populasi atau sampel tertentu, teknik pengambilan sampel pada umumnya dilakukan secara random, pengumpulan data menggunakan instrumen penelitian, analisis data bersifat kuantitatif atau statistic dengan tujuan untuk menguji hipotesis yang telah ditetapkan. Sedangkan metode kualitatif adalah metode penelitian yang berlandaskan pada filsafat postpositivisme, digunakan untuk meneliti pada kondisi obyek yang alamiah, (sebagai lawannya adalah eksperimen) dimana peneliti sebagai instrument kunci. Maka dalam penelitian ini pengambilan sampel dari semua populasi karena populasi relatif kecil kurang dari 
42 CIVICUS I Pendidikan Pancasila dan Kewarganegaraan 30 orang siswa yaitu populasinya berjumlah 27 orang siswa/i.

Jenis penelitian dalam suatu unit penelitian tergantung dari gejala yang akan diteliti. Jika gejala yang diteliti itu telah ada secara wajar dilapangan maka digunakan metode empiris, sebaliknya jika gejala yang diteliti sengaja dibuat maka digunakan dalam suatu penelitian pada umumnya dibagi menjadi dua yaitu pendekatan non eksperimen dan eksperimen. Yang dimaksud dengan pendekatan non eksperimen adalah suatu pendekatan yang digunakan dimana gejala yang diteliti telah ada secara wajar sedangkan pendekatan eksperimen adalah suatu pendekatan yang dimana yang diteliti sengaja diadakan.

Dalam penelitian ini jenis metode yang digunakan adalah metode eksperimen dengan pendekatan diskriptif kuantitatif, karena data yang diinginkan berupa data diskriptif atau pemaparan dari suatu peristiwa, kegiatan atau fakta yang diteliti. Penelitian diskriptif kuantitatif adalah masalah yang akan diteliti yaitu masalah dalam bentuk angka-angka. (Suharsimi Arikunto, 2006:239). Sedangkan menurut pendapat lain, penelitian diskriptif kuantitatif yaitu penelitian yang berusaha untuk menuturkan pemecahan masalah yang ada sekarang berdasarkan data-data, menyajikan data, menganalisis dan menginterpretasi.

Metode kuantitatif digunakan untuk memperoleh data diskriptif tentang tingkah laku dan fenomena yang terjadi berdasarkan pengamatan maupun pengakuan atau tulisan dari subyek. Metode penelitian eksperimen dapat diartikan sebagai metode penelitian yang digunakan untuk mencari pengaruh perlakuan tertentu terhadap yang lain dalam kondisi yang terkendalikan (Sugiyono, 2011:72). Eksperimen adalah suatu cara untuk mencari hubungan sebab-akibat (hubungan kausal) antara dua faktor yang disengaja ditimbulkan oleh penelitian dengan mengurangi atau menyisihkan faktor-faktor yang mengganggu. Eksperimen dilakukan dengan maksud untuk melihat akibat dari suatu perlakuan (Arikunto, 2006:84).

Adapun bentuk eksperimen di dalam melakukan penelitian diantaranya:

a. Desain pre eksperimen (one shot case study, prates pasca-tes atau satu kelompok, dan statis dua kelompok).

b. Desain true eksperimen (pasca-tes subyek acak dua kelompok, pasca-tes subyek acak sepadan dua kelompok, prates-pasca-tes kelompok acak).

c. Desain quasi eksperimen (prates-pascate kelompok control tanpa acak). (Sundara K, 2012:40).

Dalam penelitian ini metode yang digunakan adalah metode pre-eksperimen dengan satu kelompok eksperimen. Rancangan penelitian yang dipilih adalah model one group pretes-posttes desain. Kelas yang digunakan dalam penelitian ini adalah satu kelas.

Adapun desain pre-eksperimen dengan model one group pretes-posttes yakni:

\begin{tabular}{|c|c|c|}
\hline Pre - Test & Perlakuan & Post - Test \\
\hline 01 & $\mathrm{X}$ & 02 \\
\hline
\end{tabular}

Keterangan:

01 = pre-test (sebelum perlakuan)

$\mathrm{X}=$ perlakuan

02 = post-test (setelah perlakuan)
Vol. 4, No. 2, September 2016, hal 40-50

\section{GAMBARAN UMUM LOKASI PENELITIAN}

Keadaan sekolah merupakan keadaan yang sebenarnya tentang SMPN 3 Mataram. SMPN 3 Mataram dibangun di atas areal seluas 3.275 meter persegi. Ruangan yang ada di SMPN 3 Mataramterdiri atas 21 ruanganyang dibangun dalam dua tingkatyang digunakan pada pagi dan sore hari. Selain ruang kelas. Terdapat pula ruang-ruang lain seperti ruangkepala sekolah yang terbagi atas dua ruangan. Ruang elektro, perpustakaan, ruang laboratorium. Ruangkopsis, ruang BP/BK. selain itu. SMPN 3 Mataram juga memiliki fasilitas umum yang dapat yang digunakan oleh semua pihak. Fasilitas-fasilitas tersebut adalah sebuah mushalla, toilet dan lapangan olah raga (lapangan basket, volli. dan sepak bola).

Gedung-gedung tersebut di bangun dan diatur sedemikian rupa sehingga warga sekolah dapat beraktivitas dengan nyaman.

\section{1) Keadaan fisik sekolah}
a. Luas tanah seluruhnya: $3 \cdot 275,00 \mathrm{~m}^{2}$
Luas Bangunan : 1.792,00 $\mathrm{m}^{2}$
b. Luas Pekarangan : 1.33,00 m²
c. Luas Kebun Sekolah: 350,00 m²

\section{2) Lokasi Sekolah}

SMP Negeri 3 Mataram merupakan salah satu sekolah yang berada dalam wilayah Kota Madya Mataram. Sekolah ini terletak di jalan Niaga I No. 39 Ampenan Mataram. Adapun batas-batas wilayah sekolah ini adalah :

Sebelah Barat :Pemukiman Penduduk

Sebelah Timur :Pasar AmpenanBarata

Sebelah Selatan:Pemukiman Penduduk

Sebelah Utara :Pemukiman Penduduk

\section{a. Keadaan sarana dan prasarana}

Dilihat dari kondisi fisik dan keberadaan sarana dan prasarana yang dimiliki maka SMP Negeri 3 Mataram dapat digolongkan sebagai SMP yang memiliki kategori baik karena keberadaan gedung dan sarana dan prasarana yang ada cukup menunjang kegiatan pembelajaran.

\section{b. Keadaan guru}

SMP Negeri 3 Mataram tergolong madrasah yang memiliki guru yang kurang mamadai, selain itu para guru yang ada juga sebagiaannya mengajar pada bidang studi yang tidak sesuai dengan latar belakang pendidikannya. Kondisi guru di SMP Negeri 3 Mataram memiliki guru yang sangat memadai dengan jumlah guru sebanyak 26 guru yang berasal dari guru PNS dan guru diperbantukkan. Dan sebagian besar guru di SMP Negeri 3 Mataram berkualitas S-1 (Sarjana).

\section{c. Keadaan Siswa}

Mengenai keadaa siswa SMP Negeri 3 Mataram dengan jumlah siswa-siswa SMP egeri 3 Mataram tahun ajaran 2012/2013 sebanyak 707 peserta didik .

\section{METODE PENENTUAN SUBJEK}

Dalam menentukan metode penentuan subyek penelitian makan Penelitian ini adalah penelitian populasi. Studi atau penelitiannya juga disebut studi populasi atau studi sensus.

Dalam hal ini yang menjadi populasi dalam penelitian adalah siswa SMP Negeri 3 Mataram tahun pelajaran 2012/2013 yang berjumlah 27 siswa/i. Dalam 
penelitian ini yang dijadikan populasi hanya kelas VII.1 saja yang berjumlah 27 siswa/i.

\section{METODE PENGUMPULAN DATA}

Metode pengumpulan data yang digunakan dalam penelitian ini adalah sebagai berikut:

\section{a. MetodeTes}

Metode Tes adalah serentetanatau latihan yang digunakan untuk mengukur keterampilan,pengetahuan,sikap,intelegensi,kemampua $\mathrm{n}$ atau bakat yang dimiliki oleh individu atau kelompok(Ryanto,2001:103). Untuk mengetahui keefektifan suatu metode mengajar dengan terlebih dahulu melakukan tes baik sebelum maupun sesudah perlakuan terhadap populasi penelitian.

Dari pendapat di atas, maka untuk memperoleh data yang seperti diinginkan peneliti dan metode yang digunakan dalam penelitian ini adalah metode tes, yakni tes awal (Pre Test) dan tes akhir (Post Test).

a. Tes Awal (Pre Test)

Pretest ini dilakukan untuk mengetahui kemampuan awal hasil belajar siswa pada mata pelajaran PKn dari siswa sebelum melakukan perlakuan. Butir soal tes diadaptasi dari buku penunjang PKn kelas VII dengan bentuk butir soal objektif 20 butir. Pelajaran PKn disimak oleh siswa diadaptasi atau disesuaikan dengan tujuan pembelajaran yang ditetapkan.

b. Tes Akhir (Post Tes)

Tes hasil belajar PKn dilakukan untuk mengukur perolehan hasil belajar setelah menerakan model pembelajaran berbasis modeling dengan jumlah soal sebanyak 20 butir yang telah disediakan oleh peneliti.

Dalam penyusunan instrumen tes hasil belajar sudah memperhatikan unsur kevaliditasnya yaitu: mengukur soal sesuai dengan materi atau isi pembelajaran yang diberikan dan sesuai dengan kompetensi dasar (KD).

\section{b. Metode Observasi}

Observasi adalah teknik yang didasarkan atas pengalaman secara langsung, yang memungkinkan melihat dan mengamati sendiri secara langsung, kemudian mencatat perilaku atau kejadian dan kondisi fisik sebagaimana yang terjadi dalam keadaan sebenarnya (Moleong, 2005: 174)

Dari pendapat ahli di atas dapat ditarik kesimpulan bahwa metode observasi adalah suatu metode pengumpulan data dengan mengadakan pengamatan dan peninjauan berbagai peristiwa yang berkembang di lapangan sekaligus mengadakan pencatatan secara struktural agar fenomena di lokasi penelitian tidak ada yang ketinggalan.

\section{c. Metode Dokumentasi}

Dokumentasi menurut ahli "metode dokumentasi yakni suatu alat pengumpulandata yang diartikan sebagai salah satu tekhnikpengumpulan data dengan cara meneliti dan mencatat benda-benda tertulis, gambar-gambar dan lain-lain yang berhubungan dengan objek penelitian" (Arikunto, 2006:158).

Jadi dari teori di atas metode dokumentasi bertujuan untuk mendapatkaninformasi dalam bentuk dokumen-dokumen atau arsip-arsip yang berbentuk tertulis yang sudah ada di objek penelitian. Dokumentasi ini bisa diambil di objek penelitian atau arsip-arsip sekolah yang membidanginya.

\section{JENIS DAN SUMBER DATA a. Jenis Data}

Pada umumnya jenis data terbagi atas data kualitatif dan kuantitatif. Data kualititatif adalah jenis data yang berbentuk kata-kata, kalimat atau pendapat dari responden atau informasi penelitian. Sedangkan data kuantitatif data yang berbentuk angka, atau data kualitatif yang diangkakan (Skoring). Namun demikian, data dalam penelitian ini selalu dihubungkan dengan skala pengukuran.

Menurut (Sundara K, 2012:27) skala pengukuran dapat berupa yaitu:

1. Skala nominal adalah disusun berdasarkan jenis, kategori, atau pemilahan, seperti agama yang di anut : islam, kristen, hindu, budha.

2. Skala ordinal adalah disusun berdasarkan ranking, seperti mengukur rangking dalam suatu pertandingan : juara I, II, dan III.

3. Skala interval adalah skala yang menunjukkan jarak antara satu data dengan data yang lain mempunyai bobot yang sama, seperti indeks prestasi IP 1-4, 1-100. Dst, dan

4. Skala ratio adalah skala pengukuran yang mempunyai nilai nol mutlak, dan memepunyai jarak yang sama (merupakan bilangan yang sebenarnya), seperti ukuran meter, kilogram, dll.

Dari pendapat di atas, jenis data kuantitatif yang digunakan dalam penelitian ini adalah data interval yaitu mencari peningkatan aktivitas dan hasil belajar siswa antara sebelum dan sesudah penggunaan penerapan model pembelajaran kontekstual berbasis modeling pada mata pelajaran PKn kelas VII.1 di SMP Negeri 3 Mataram.

\section{b. Sumber Data}

Sumber data dalam penelitian ini menggunakan sumber data primer dan sekunder. Data primer dalam penelitian ini tes hasil belajar siswa dan hasil observasi belajar siswa. Sedangkan data sekunder dalam penelitian ini adalah hasil penelitian dari hasil dokumentasi dilapangan.

\section{INDETIFIKASI DAN \\ OPERASIONAL VARIABEL}

\section{a. Indentifikasi Variabel}

Variabel adalah "objek penelitian atau apa yang menjadi titik perhatian suatu penelitian" (Arikunto, 2006:93). Sedangkan menurut (Sundara K, 2012:28), variabel merupakan suatu sifat atau nilai dari orang, subyek atau kegiatan yang mempunyai variasi tertentu yang ditetapkan oleh peneliti.

Dalam penelitian variabel dikelompokkan menjadi dua yaitu:

a. Variabel bebas yaitu variabel yang mempengaruhi variabel lainnya atau mengakibatkan variabel lainnya berubah.

b. Variabel terikat yaitu variabel yang dipengaruhi oleh variabel bebas (Sugiono, 2006:3)

Dari pendapat para ahli di atas dapat disimpulkan bahwa variabel merupakan suatu gejala atau obyek yang akan diteliti dan menjadi suatu titik perhatian dalam penelitian dan merupakan suatu obyek atau kegiatan yang mempunyai variasi tertentu yang ditetapkan oleh peneliti. 
Ada dua jenis variabel yaitu: a). Variabel bebas (indevenden variabel) yaitu variabel yang secara bebas berpengaruh terhadap variabel lain (variabel terikat). Variabel biasanya dilambangkan dengan variabel X. b). Variabel terikat (dependen variabel) yaitu variabel yang dipengaruhi oleh variabel lain (variabel terikat) sehingga seringkali juga disebut dengan dependen variabel. Variabel ini biasanya dilambangkan dengan variabel $\mathrm{Y}$. (Suharsimi Arikunto,2006:93)

Dalam penelitian ini variabel $\mathrm{X}$ adalah pembelajaran kontekstual berbasis modeling. Sedangkan variabel $\mathrm{Y}$ adalah aktivitas dan hasil belajar siswa PKn.

\section{DEFINISI OPERASIONAL VARIABEL}

Makna judul dalam penelitian ini, perlu dijelaskan istilah-istilah sebagai berikut :

a. Pembelajaran kontekstual merupakan bagian dari kerangka pendidikan yang dapat digunakan untuk membantu siswa dan membuat pembelajaran menjadi lebih bermakna bagi siswa. Guru harus memiliki konteks pembelajaran yang tepat bagi siswa dengan cara mengaitkan pembelajaran dengan budaya yang berlaku dalam kehidupan siswa.

b. Pembelajaran kotekstual modeling merupakan proses pembelajaran dengan memperagakan suatu contoh yang dapat ditiru oleh siswa. Sebagai contoh mengoperasikan instrumen memerlukan contoh agar siswa dapat mengerjakan dengan benar (Sugiyanto, 2010: 15).

c. Pengertian Aktivitas merupakan serangkaian kegiatan pembelajaran yang dilakukan siswa selama proses pembelajaran.Dengan melakukan berbagai aktivitas dalam kegiatan pembelajaran diharapkan siswa dapat membangun pengetahuannya sendiri tentang materi PendidikanPancasila dan Kewarganegaran (PKn) dengan bantuan guru.Dalam hal ini, aktivitas yang diamati selama kegiatan pembelajaran berlangsung dibatasi pada ruang lingkup.

\section{d. Pengertian Hasil Belajar}

Hasil belajar adalah hasil yang dicapai oleh seseorang karena usahanya untuk memiliki sesuatu kecakapan, ilmu pengetahuan atau perubahan-perubahan yang dicapai seseorang dalam usahanya untuk memiliki suatu kecakapan maupun keterampilan-keterampilan tertentu.

Jadi yang dimaksud dengan hasil belajar pada penelitian ini adalah suatu hasil yang dicapai oleh siswa setelah melaksanakan proses belajar mengajar.

\section{TEKNIK ANALISIS DATA}

\section{a. Analisis Data Hasil Belajar}

Analisis data merupakan cara yang digunakan untuk mengelola data yang diperoleh dari berbagai metode sehingga dapat diperoleh informasi-informasi yang berguna dan berhasil sebagaimana yang diharapkan. Data yang didapat dianalisis dengan teliti sehingga dapat disimpulkan sebagai laporan penelitian.

Dalam penelitian ini data berbentuk kuantitatif, yaitu yang direalisasikan atau diwujudkan dalam bentuk angka. Dalam analisa data yang terkumpul, peneliti menggunakan analisis statistik sehingga rumus yang digunakan adalah T-tes.
Vol. 4, No. 2, September 2016, hal 40-50

$$
\mathrm{t}=\frac{\mathrm{MLA}}{\sqrt{\frac{E R^{2} d}{N(N-1)}}}
$$

Keterangan:

$\mathrm{t}=$ nilai thitung

$\mathrm{M}_{\mathrm{d}}=$ mean dari perbedaan dari pre-test dan post-test

$\mathrm{Xd}=$ deviasi masing-masing subjek (d-Md)

$\sum \mathrm{X}^{2} d=$ jumlah kuadrat deviasi

$\mathrm{N}=$ jumlah subjek pada sampel

d.b.= ditentukan dengan N-1 (Suharsimi

Arikunto,2006:306).

\section{b. Analisis Data Hasil Observasi Aktivitas Belajar}

Peningkatan belajar siswa dapat diketahui melalui hasil observasi terhadap perilaku siswa selama mengikuti proses pembelajaran. Aktivitas belajar siswa dapat diamati dan dicatat dengan menggunakan lembar observasi. Serta dapat dianalisis dengan cara sebagai berikut:

a) Menentukan skor aktivitas belajar siswa

Skor setiap siswa tergantung dari banyaknya individu yang melaksanakan deskriptor pada lembar observasi.

1. Skor 4 diberikan jika semua deskriptor yang nampak.

2. Skor 3 diberikan jika 2 deskriptor nampak

3. Skor 2 diberikan jika 1 deskriptor nampak

4. Skor 1 diberikan jika tidak deskriptor Nampak

5. Nurkencana(dalam Nurkhamariah, 2009:37)

b) Menentukan MI dan SDI

Untukmengetahui aktivitas dalam pembelajaran, maka data hasil observasi yang berupa skor diolah dengan rumus :

$$
A=\frac{\sum X}{i}
$$

Keterangan :

A = Skor rata-rata aktivitas belajar siswa

$\sum X=$ Jumlah skor aktivitas belajar seluruhnya

$\mathrm{I}=$ Banyaknya item.

Skor Maksimal Ideal (SMI) merupakan skor tertinggi aktivitas yang diperoleh apabila semua indikator yang diamati nampak yaitu skor 4. Untuk menilai kategori aktivitas siswa, ditentukan terlebih dahulu $M I$ dan $S D I$ dengan rumus sebagai berikut

$$
\begin{aligned}
& \mathrm{MI}=\frac{1}{2}(\text { Skor Max }+ \text { Skor Min }) \\
& \mathrm{SDI}=\frac{1}{\mathrm{a}} \mathrm{x} \text { MI }
\end{aligned}
$$

Keterangan :

$\mathrm{MI}=$ Mean Ideal.

\begin{tabular}{|c|c|c|}
\hline Interval & $\begin{array}{c}\text { Interval } \\
\text { Skor }\end{array}$ & Kriteria \\
\hline $\mathrm{A} \geq \mathrm{MI}+1,5 \mathrm{SDI}$ & $\mathrm{A} \geq 22,5$ & SangatAktif \\
\hline $\begin{array}{l}\mathrm{MI}+0,5 \mathrm{SDI} \leq \\
\mathrm{A}<\mathrm{MI}+1,5 \mathrm{SDI}\end{array}$ & $\begin{array}{l}17,5 \leq \mathrm{A} \\
<22,5\end{array}$ & Aktif \\
\hline $\begin{array}{l}\mathrm{MI}-\mathrm{O}, 5 \\
\mathrm{SDI} \leq \mathrm{A}<\mathrm{MI}+ \\
0,5 \mathrm{SDI}\end{array}$ & $\begin{array}{l}12,5 \leq \mathrm{A} \\
<17,5\end{array}$ & CukupAktif \\
\hline $\begin{array}{l}\mathrm{MI}-1,5 \\
\mathrm{SDI} \leq \mathrm{A}<\mathrm{MI}- \\
0,5 \mathrm{SDI}\end{array}$ & $\begin{array}{l}7,5 \leq \mathrm{A} \\
<12,5\end{array}$ & KurangAktif \\
\hline $\mathrm{A}<\mathrm{MI}-1,5 \mathrm{SDI}$ & $\mathrm{A}<7,5$ & $\begin{array}{c}\text { SangatKura } \\
\text { ngAktif }\end{array}$ \\
\hline
\end{tabular}

SDI $=$ Standar Deviasi Ideal

Tabel 3.1

Pedoman Skor Standar Aktivitas Belajar Siswa

\section{HASIL DAN PEMBAHASAN}




\section{DISKRIPSI DATA}

Wawancara yang di lakukan dengan guru PKn dan siswa yang ada di SMP Negeri 3 Mataram. Wawancara dengan guru PKn diperoleh informasi mengenai jadwal pelajaran PKn yang ada di sekolah, proses pembelajaran PKn yang ada di SMP Negeri 3 Mataram berjalan dengan cukup baik namun fasilitas penunjangnya masih kurang seperti buku-buku paket PKn serta buku-buku penunjang lainnya, sehingga dalam proses pembelajarannya masih didominasi oleh guru.

Peneliti setelah mendapatkan informasi mengenai jadwal penelitian maupun kegiatan pembelajarannya, pada proses pelaksanaan belajar mengajar, terlebih dahulu diberikan tes awal. Tes ini diberikan dengan tujuan untuk mengukur pemahaman awal siswa terhadap materi yang akan disampaikan. Dari hasil belajar tersebut peneliti dapat menganalisis kemampuan siswa dan dapat digunakan sebagai acuan atau pandangan untuk menyampaikan materi kepada siswa.

Data yang diperoleh dari hasil penelitian ini ada dua yaitu pertama data yang diperoleh dari hasil evaluasi tes hasil belajar siswa. Data yang kedua yaitu data hasil observasi yang berupa data aktivitas belajar siswa selama proses belajar mengajar berlangsung.

Sebagai langkah konkrit dalam menyelesaikan permasalahan tersebut, maka perlu disajikan data-data yang diperoleh di lapangan, untuk lebih jelasnya berikut ini adalah data-data yang diperoleh di lapangan.

a. Data tentang nama-nama siswa kelas VII. 1 yang dijadikan populasi penelitian di kelas VII. 1 SMP Negeri 3 Mataram, Tahun Pelajaran 2012/2013.

\begin{tabular}{|c|c|c|c|}
\hline No & Nama Siswa & $\begin{array}{c}\text { Jenis } \\
\text { Kela } \\
\text { min } \\
\text { L/P }\end{array}$ & $\begin{array}{l}\text { Nilai } \\
\text { Hasil } \\
\text { Belaja } \\
\text { Siswa } \\
\text { (Pre- } \\
\text { Tesr) } \\
\end{array}$ \\
\hline 1 & $\begin{array}{l}\text { Alya Junika } \\
\text { Pratiwi }\end{array}$ & $\mathrm{P}$ & 65 \\
\hline 2 & $\begin{array}{l}\text { Andika Indrajaya } \\
\mathrm{L}\end{array}$ & $\mathrm{L}$ & 80 \\
\hline 3 & Baiq Bunga Suciati & $\mathrm{P}$ & 35 \\
\hline 4 & Baiq Haerun Nisa & $\mathrm{P}$ & 60 \\
\hline 5 & Desfira Dwitasya L & $\mathrm{P}$ & 55 \\
\hline 6 & Egar Zulfa & $\mathrm{L}$ & 60 \\
\hline 7 & Fadilah & $P$ & 85 \\
\hline 8 & Fandika & $\mathrm{L}$ & 50 \\
\hline 9 & Febriani & $\mathrm{P}$ & 55 \\
\hline 10 & $\begin{array}{l}\text { Heri Aji } \\
\text { Kurniawan }\end{array}$ & $\mathrm{L}$ & 30 \\
\hline 11 & I Made Megantara & $\mathrm{L}$ & 45 \\
\hline 12 & Ilham Jayadi & $\mathrm{L}$ & 75 \\
\hline 13 & Indra Wahyudi & $\mathrm{L}$ & 70 \\
\hline 14 & Ira Wahyuni & $\mathrm{P}$ & 80 \\
\hline 15 & Jefri Ahmad G & $\mathrm{L}$ & 75 \\
\hline 16 & Leni Mardiana & $\mathrm{P}$ & 50 \\
\hline 17 & M. Marcelino & $\mathrm{L}$ & 80 \\
\hline 18 & Nandini & $\mathrm{P}$ & 65 \\
\hline 19 & Ni Luh Wulandari & $\mathrm{P}$ & 85 \\
\hline 20 & $\begin{array}{l}\text { Rahmad } \\
\text { Ardiansyah }\end{array}$ & $\mathrm{L}$ & 85 \\
\hline 21 & $\begin{array}{l}\text { Ravita Kurnia } \\
\text { Putri }\end{array}$ & $\mathrm{P}$ & 70 \\
\hline 22 & $\begin{array}{l}\text { Riki Maulana } \\
\text { Hakim }\end{array}$ & $\mathrm{L}$ & 50 \\
\hline 23 & Rizaldi Akbar & $\mathrm{L}$ & 65 \\
\hline 24 & Rukmana Ningsih & $\mathrm{P}$ & 65 \\
\hline 25 & Roberto Fedricho & $\mathrm{L}$ & 70 \\
\hline 26 & Sahlan & $\mathrm{L}$ & 40 \\
\hline \multirow[t]{2}{*}{27} & Ulfa Indriyani & $\mathrm{P}$ & 95 \\
\hline & $\mathrm{N}=27$ & & $\mathrm{X} 1=1740$ \\
\hline
\end{tabular}

Untuk lebih jelasnya dapat dilihat pada tabel berikut: Tabel 4.1

Nama-nama Siswa Kelas VII. 1 yang di jadikan Populasi Penelitian di Kelas VII. 1 SMP Negeri 3 Mataram, Tahun Pelajaran 2012/2013

\begin{tabular}{|c|c|c|c|}
\hline No & Nama Siswa & $\begin{array}{l}\text { Jenis } \\
\text { Kelamin } \\
\text { L/P }\end{array}$ & Ket \\
\hline 1 & Alya Junika Pratiwi & $\mathrm{P}$ & \\
\hline 2 & Andika Indrajaya L & $\mathrm{L}$ & \\
\hline 3 & Baiq Bunga Suciati & $\mathrm{P}$ & \\
\hline 4 & Baiq Haerun Nisa & $\mathrm{P}$ & \\
\hline 5 & Desfira Dwitasya L & $\bar{P}$ & \\
\hline 6 & Egar Zulfa & $\mathrm{L}$ & \\
\hline 7 & Fadilah & $\mathrm{P}$ & \\
\hline 8 & Fandika & $\mathrm{L}$ & \\
\hline 9 & Febriani & $\mathrm{P}$ & \\
\hline 10 & Heri Aji Kurniawan & $\mathrm{L}$ & \\
\hline 11 & I Made Megantara & $\mathrm{L}$ & \\
\hline 12 & Ilham Jayadi & $\mathrm{L}$ & \\
\hline 13 & Indra Wahyudi & $\mathrm{L}$ & \\
\hline 14 & Ira Wahyuni & $\mathrm{P}$ & \\
\hline 15 & Jefri Ahmad G & $\mathrm{L}$ & \\
\hline 16 & Leni Mardiana & $\mathrm{P}$ & \\
\hline 17 & M. Marcelino & $\mathrm{L}$ & \\
\hline 18 & Nandini & $\mathrm{P}$ & \\
\hline 19 & Ni Luh Wulandari & $\mathrm{P}$ & \\
\hline 20 & $\begin{array}{l}\text { Rahmad } \\
\text { Ardiansyah }\end{array}$ & $\mathrm{L}$ & \\
\hline 21 & Ravita Kurnia Putri & $\mathrm{P}$ & \\
\hline 22 & $\begin{array}{l}\text { Riki Maulana } \\
\text { Hakim }\end{array}$ & $\mathrm{L}$ & \\
\hline
\end{tabular}




\begin{tabular}{|c|l|c|c|}
\hline 23 & Rizaldi Akbar & L & \\
\hline 24 & Rukmana Ningsih & P & \\
\hline 25 & Roberto Fedricho & L & \\
\hline 26 & Sahlan & L & \\
\hline 27 & Ulfa Indriyani & P & \\
\hline \multicolumn{4}{|c|}{ Sumber: SMP Negeri 3 Mataram }
\end{tabular}

b. Data tentang hasil belajar siswa

Data dari hasil penelitian ini terdiri dari hasil belajar siswa sebelum menggunakan model pembelajaran kontekstual berbasis modeling dan hasil belajar siswa sesudah menggunakan model pembelajaran kontekstual berbasis modeling.

Adapun data mengenai hasil belajar siswa sebelum menggunakan model pembelajaran kontekstual berbasis modeling dapat dilihat pada tabel berikut:

Tabel 4.2

Data Hasil Belajar Siswa Kelas VII.1 SMP Negeri 3

Mataram, Tahun Pelajaran 2012/2013 (Pre-Test)

Sumber: data dari rekapitulasi nilai pre-test siswa

kelas VII.1 (lampiran 1)

Keterangan: $\mathrm{N}=\mathbf{2 7}$

$\mathrm{X} 1=\frac{\text { jwiah selurwh nilai siswa }}{N}=\frac{1740}{27}=64.44$

Dari tabel di atas diperoleh nilai rata-rata hasil evaluasi awal siswa 64.44 yang dilakukan oleh peneliti sebelum menggunakan model kontekstual berbasis modeling (pre-test).

\section{Mencari Range Data Interval}

$\mathrm{K}=1+3 \cdot 3 \log \mathrm{n}$

$=1+3 \cdot 3 \log 27$

$=1+3 \cdot 3(1.4313)$

$=1+4.72$

$=5.72($ dibulatkan menjadi 6$)$.

$\mathrm{R}=($ skor tertinggi-skor terendah $)+1$

$=(95-30)+1$

$=65+1$

$=66$

$$
\begin{aligned}
\mathrm{I} & =\frac{R}{K} \\
& =\frac{66}{6}=11
\end{aligned}
$$

Penyeberan atau distribusi nilai siswa (Pre-Test)

$\begin{array}{llllll}65 & 80 & 35 & 60 & 55 & 60 \\ & 85 & 50 & 55 & 30 & \\ 45 & 75 & 70 & 80 & 75 & 50 \\ & 80 & 65 & 85 & 85 & \\ 70 & 50 & 65 & 65 & 70 & 40 \\ & 95 & & & & \end{array}$

Tabel 4.3

Untuk Mencari Mean dan Standar Deviasi pada Tes Awal

\begin{tabular}{|c|c|c|c|c|c|c|}
\hline & & & & & 0 & \\
\hline $30-40$ & 3 & 35 & 105 & $\begin{array}{l}- \\
28.51\end{array}$ & $\begin{array}{l}812.8 \\
2\end{array}$ & $\begin{array}{l}2438 . \\
46\end{array}$ \\
\hline $\mathrm{N}=27$ & & & \begin{tabular}{|l|}
$\mathrm{f} \mathrm{x}$ \\
1715 \\
\end{tabular} & & & $\begin{array}{l}\sum \mathrm{fx}^{2}= \\
8048\end{array}$ \\
\hline
\end{tabular}

\begin{tabular}{|l|c|c|l|l|l|l|}
\hline \multicolumn{7}{|c|}{ (Pre-Test) } \\
\hline $85-95$ & 4 & 90 & 360 & 26.49 & $\begin{array}{l}701.7 \\
2\end{array}$ & $\begin{array}{l}2806 . \\
88\end{array}$ \\
\hline $74-84$ & 4 & 79 & 316 & 15.49 & $\begin{array}{l}239.9 \\
4\end{array}$ & $\begin{array}{l}959 . \\
76\end{array}$ \\
\hline $63-73$ & 7 & 68 & 476 & 4.49 & 20.16 & $\begin{array}{l}141 . \\
12\end{array}$ \\
\hline $52-62$ & 4 & 57 & 228 & -6.51 & 42.38 & $\begin{array}{l}169 . \\
52\end{array}$ \\
\hline $41-51$ & 5 & 46 & 230 & -17.51 & 306.6 & 1533 \\
\hline
\end{tabular}

Mean

$$
=\frac{\mathbb{E} f x}{\mathbb{N}}=\frac{1715}{27}=63.51
$$

Standar deviasi $=\sqrt{\frac{8 f x^{2}}{n}}=\sqrt{\frac{8048.74}{27}}=\sqrt{298.10}=$ 17.26

Setelah diterapkan model pembelajaran kontekstual berbasis modeling pada siswa, peneliti melakukan evaluasi hasil belajar siswa. Data hasil evaluasi belajar siswa setelah menggunakan modelpembelajaran kontekstual berbasismodeling adalah sebagai berikut:

Tabel 4.4

Data Hasil Belajar Siswa Kelas VII.1 Setelah

\begin{tabular}{|c|c|c|c|}
\hline No & Nama Siswa & $\begin{array}{c}\text { Jenis } \\
\text { Kela } \\
\text { min } \\
\text { L/P }\end{array}$ & $\begin{array}{l}\text { Nilai } \\
\text { Hasil } \\
\text { Belajar } \\
\text { Siswa } \\
\text { (Post-Test) }\end{array}$ \\
\hline 1 & Alya Junika Pratiwi & $\mathrm{P}$ & 80 \\
\hline 2 & Andika Indrajaya L & $\mathrm{L}$ & 75 \\
\hline 3 & Baiq Bunga Suciati & $\mathrm{P}$ & 60 \\
\hline 4 & Baiq Haerun Nisa & $P$ & 80 \\
\hline 5 & Desfira Dwitasya L & $\mathrm{P}$ & 80 \\
\hline 6 & Egar Zulfa & $\mathrm{L}$ & 85 \\
\hline 7 & Fadilah & $\mathrm{P}$ & 80 \\
\hline 8 & Fandika & $\mathrm{L}$ & 85 \\
\hline 9 & Febriani & $\mathrm{P}$ & 80 \\
\hline 10 & Heri Aji Kurniawan & $\mathrm{L}$ & 75 \\
\hline 11 & I Made Megantara & $\mathrm{L}$ & 85 \\
\hline 12 & Ilham Jayadi & $\mathrm{L}$ & 90 \\
\hline 13 & Indra Wahyudi & $\mathrm{L}$ & 95 \\
\hline 14 & Ira Wahyuni & $\mathrm{P}$ & 95 \\
\hline 15 & Jefri Ahmad G & $\mathrm{L}$ & 95 \\
\hline 16 & Leni Mardiana & $\mathrm{P}$ & 65 \\
\hline 17 & M. Marcelino & $\mathrm{L}$ & 85 \\
\hline 18 & Nandini & $\mathrm{P}$ & 70 \\
\hline 19 & Ni Luh Wulandari & $\mathrm{P}$ & 80 \\
\hline 20 & Rahmad Ardiansyah & $\mathrm{L}$ & 95 \\
\hline 21 & Ravita Kurnia Putri & $\mathrm{P}$ & 70 \\
\hline 22 & Riki Maulana Hakim & $\mathrm{L}$ & 95 \\
\hline 23 & Rizaldi Akbar & $\mathrm{L}$ & 95 \\
\hline 24 & Rukmana Ningsih & $P$ & 70 \\
\hline 25 & Roberto Fedricho & $\mathrm{L}$ & 85 \\
\hline 26 & Sahlan & $\mathrm{L}$ & 70 \\
\hline \multirow[t]{2}{*}{27} & Ulfa Indriyani & $\mathrm{P}$ & 100 \\
\hline & $\mathrm{N}=27$ & & $\mathrm{X} 2=2.220$ \\
\hline
\end{tabular}
Menggunakan Model Pembelajaran Kontekstual Berbasis Modeling (Post-Test)

Sumber: Data dari rekapitulasi nilai post-test siswa kelas VII (lampiran 2)

$\mathrm{X} 2=\frac{\text { jumiah nilaigeluruh siswa }}{N}=\frac{2.220}{27}=82.22$

Dari tabel di atas diperoleh nilai rata-rata siswa setelah diajarkan dengan menggunakanmodelpembelajaran kontekstual berbasis modeling sebesar 82,22.

$$
\begin{aligned}
& \text { Mencari range data interval } \\
& \begin{aligned}
\mathrm{K}= & 1+3 \cdot 3 \log \mathrm{n} \\
& =1+3 \cdot 3 \log 27 \\
& =1+3 \cdot 3(1.4313) \\
& =1+4 \cdot 72 \\
& =5 \cdot 72(\text { dibulatkan menjadi } 6)
\end{aligned} \\
& \mathrm{R}=(\text { skor tertinggi-skor terendah) }+1
\end{aligned}
$$




$$
\begin{aligned}
& =(100-60)+1 \\
& =40+1 \\
& =41 \\
I= & \frac{R}{K} \\
= & \left.\frac{41}{6}=6.83 \text { (dibulatkan menjadi } 7\right)
\end{aligned}
$$

Penyebaran atau Distribusi Nilai Siswa (PostTest)

$\begin{array}{llllll}80 & 75 & 60 & 80 & 80 & 85 \\ & 80 & 85 & 80 & 75 & \\ 85 & 90 & 95 & 95 & 95 & 65 \\ & 85 & 70 & 80 & 95 & \\ 70 & 95 & 95 & 70 & 85 & 70 \\ & 100 & & & \end{array}$

Tabel 4.5

Untuk Mencari Mean dan Standar Deviasi (Post-Test)

\begin{tabular}{|c|c|l|l|l|l|l|}
\hline Interval & $\begin{array}{c}\text { Freku } \\
\text { ensi F }\end{array}$ & $\begin{array}{c}\text { Mean } \\
/ \mathbf{X}\end{array}$ & $\mathbf{F X}$ & $\begin{array}{c}\mathbf{X} \\
\text { (x-mean) }\end{array}$ & $\mathbf{X}^{2}$ & $\mathbf{F X}^{\mathbf{2}}$ \\
\hline $95-100$ & 7 & 98 & 686 & 15.82 & $\begin{array}{l}250 . \\
27\end{array}$ & $\begin{array}{l}1751 . \\
89\end{array}$ \\
\hline $88-94$ & 1 & 91 & 91 & 8.82 & $\begin{array}{l}77.7 \\
9\end{array}$ & $\begin{array}{l}77 \cdot 7 \\
9\end{array}$ \\
\hline $81-87$ & 5 & 84 & 420 & 1.82 & 3.31 & $\begin{array}{l}16.5 \\
5\end{array}$ \\
\hline $74-80$ & 8 & 77 & 616 & -5.18 & $\begin{array}{l}26.8 \\
3\end{array}$ & $\begin{array}{l}214 . \\
64\end{array}$ \\
\hline $67-73$ & 4 & 70 & 280 & -12.18 & $\begin{array}{l}148 . \\
35\end{array}$ & $\begin{array}{l}593 \\
4\end{array}$ \\
\hline $60-66$ & 2 & 63 & 126 & -19.18 & $\begin{array}{l}367 . \\
87\end{array}$ & $\begin{array}{l}735 \\
74\end{array}$ \\
\hline total & $\mathrm{N}=27$ & $\sum \mathrm{fx}=2219$ & $2 \mathrm{fx}^{2}=3390.01$ & \\
\hline
\end{tabular}

Mean

$$
=\frac{\mathbb{L F x}}{N}=\frac{2219}{27}=82.18
$$

Standar deviasi $=\sqrt{\frac{2 f x^{2}}{n}}=\sqrt{\frac{2 a 90.01}{27}}=\sqrt{125.55}=11.20$

Berdasarkan perhitungan hasil penelitian pada tabel di atas diperoleh deskriptif data pada tabel 6.

\begin{tabular}{|l|l|l|}
\hline Statistik & X1 & X2 \\
\hline Rata-rata (mean) & 63.51 & 82.18 \\
\hline Nilai maksimum & 95 & 100 \\
\hline Nilai minimum & 30 & 60 \\
\hline Standar deviasi & 17.26 & 11.20 \\
\hline $\begin{array}{l}\text { Nilai maksimum yang } \\
\text { diharapkan }\end{array}$ & 100 & 100 \\
\hline Ketuntasan belajar & 44.44 & 92.59 \\
\hline Hasil belajar & 64.44 & 82.22 \\
\hline Aktivitas belajar & 18.07 & 22.44 \\
\hline
\end{tabular}

Berdasarkan hasil tes yang dilakukan oleh peneliti dengan memberikan tes awal (Pre-Test) kepada siswa sebelum menggunakan model pembelajaran modeling terdapat perbedaan yang signifikan. Ini ditunjukkan dengan nilai rata-rata siswa sebelum menggunakan model pembelajaran modeling adalah 64.44. Kemudian setelah peneliti menerapkan model pembelajaran modeling nilai rata-rata hasil evaluasi siswa adalah 82.22. Ini berarti signifikan, terbukti dari adanya peningkatan nilai hasil belajar siswa sebesar 17.78.

c. Data tentang hasil observasi aktivitas belajar siswa

Adapun data hasil observasi kegiatan belajar siswa yang diperoleh pada proses pembelajaran yang tidak diterapkan model pembelajaran kontekstual modeling, yaitudiperoleh nilai rata-rata sebesar 18.07 dengan kategori aktif. Dilihat dirumus dibawah:

$$
\begin{aligned}
\mathrm{A}= & \frac{\square x}{\mathrm{i}}=\frac{489}{27} \\
& =18.07
\end{aligned}
$$

Sedangkan untuk hasil observasi belajar siswa setelah diterapkan model pembelajaran kontekstual modeling yaitu diperoleh nilai rata-ratasebesar 22.44 dengan katergori sangat aktif, dilihat dirumus dibawah ini:

$$
\begin{aligned}
& \mathrm{A}=\frac{\sqrt{x}}{\mathrm{i}}=\frac{606}{27} \\
& =22.44
\end{aligned}
$$

Berdasarkan hasil observasi yang dilakukan oleh peneliti dengan mengamati proses pembelajaran pada awal tes (pre-test) kepada siswa sebelum menerapkan model pembelajaran berbasis modeling dengan nilai rata-rata sebesar 18.07 dengan kategori yang cukup aktif. Dan terdapat perbedaan yang cukup signifikan dengan hasil observasi setelah menerapkan model pembelajaran berbasis modeling dengan nilai rata-rata sebesar 22.44 dengan kategori sangat aktif. Berarti dengan model pembelajaran modeling dapat meningkatkan aktivitas belajar siswa.

\section{ANALISIS DATA}

Berdasarkan diskripsi data di atas, maka dapat dianalisis tentang penerapan model pembelajaran

\begin{tabular}{|c|c|c|c|}
\hline No Siswa & $\begin{array}{l}\text { Pre- } \\
\text { Test }\end{array}$ & $\begin{array}{l}\text { Post- } \\
\text { Test }\end{array}$ & $\begin{array}{l}\text { Gain }(d) \\
\text { Post-Test } \\
\text { Pre-Test }\end{array}$ \\
\hline 1 & 65 & 80 & +15 \\
\hline 2 & 80 & 75 & -5 \\
\hline 3 & 35 & 60 & +25 \\
\hline 4 & 60 & 80 & +20 \\
\hline 5 & 55 & 80 & +25 \\
\hline 6 & 60 & 85 & +25 \\
\hline 7 & 85 & 80 & -5 \\
\hline 8 & 50 & 85 & +35 \\
\hline 9 & 55 & 80 & +25 \\
\hline 10 & 30 & 75 & +45 \\
\hline 11 & 45 & 85 & +40 \\
\hline 12 & 75 & 90 & +15 \\
\hline 13 & 70 & 95 & +25 \\
\hline 14 & 80 & 95 & +15 \\
\hline 15 & 75 & 95 & +20 \\
\hline 16 & 50 & 65 & +15 \\
\hline 17 & 80 & 85 & +5 \\
\hline 18 & 65 & 70 & +5 \\
\hline 19 & 85 & 80 & -5 \\
\hline 20 & 85 & 95 & +10 \\
\hline 21 & 70 & 70 & $\mathrm{O}$ \\
\hline 22 & 50 & 95 & +45 \\
\hline 23 & 65 & 95 & +30 \\
\hline 24 & 65 & 70 & +5 \\
\hline 25 & 70 & 85 & +15 \\
\hline 26 & 40 & 70 & +30 \\
\hline 27 & 95 & 100 & +5 \\
\hline $\mathrm{N}=27$ & $\begin{array}{c}1740 \\
X_{1}= \\
64.44\end{array}$ & $\begin{array}{l}2.220 \\
\mathrm{X}_{2}= \\
82.22 \\
\end{array}$ & $\sum \mathrm{d}=480$ \\
\hline
\end{tabular}
kontekstual berbasis modeling terhadap Peningkatan Aktivitas dan Hasil Belajar Siswa pada Mata Pelajaran PKn Kelas VII.1 SMP Negeri 3 Mataram sesudah menggunakan model pembelajaran kontekstual berbasis modeling. Untuk lebih jelasnya lihat pada tabel berikut ini:

Tabel 4.7

Nilai rata-rata hitung dari perbedaan Pre-Test dengan Post-Test

Sumber : SMP Negeri 3 Mataram 
Keterangan : $\mathrm{N}=27$

$$
\begin{aligned}
& X_{1}=64.44 \\
& X_{2}=82.22 \\
& \sum d=480
\end{aligned}
$$

\begin{tabular}{|c|c|c|c|}
\hline $\begin{array}{c}\text { No. } \\
\text { Siswa }\end{array}$ & $\mathrm{D}$ & $\begin{array}{c}\mathrm{Xd} \\
(\mathrm{d}-\mathrm{Md})\end{array}$ & $\mathrm{X}^{2} \mathrm{~d}$ \\
\hline 1 & +15 & -2.78 & 7.7284 \\
\hline 2 & -5 & -22.78 & 518.9284 \\
\hline 3 & +25 & 7.22 & 52.1284 \\
\hline 4 & +20 & 2.22 & 4.9284 \\
\hline 5 & +25 & 7.22 & 52.1284 \\
\hline 6 & +25 & 7.22 & 52.1284 \\
\hline 7 & -5 & -22.78 & 518.9284 \\
\hline 8 & +35 & 17.22 & 296.5284 \\
\hline 9 & +25 & 7.22 & 52.1284 \\
\hline 10 & +45 & 27.22 & 740.9284 \\
\hline 11 & +40 & 22.22 & 493.7284 \\
\hline 12 & +15 & -2.78 & 7.7284 \\
\hline 13 & +25 & 7.22 & 52.1284 \\
\hline 14 & +15 & -2.78 & 7.7284 \\
\hline 15 & +20 & 2.22 & 4.9284 \\
\hline 16 & +15 & -2.78 & 7.7284 \\
\hline 17 & +5 & -12.78 & 163.3284 \\
\hline 18 & +5 & -12.78 & 163.3284 \\
\hline 19 & -5 & -22.78 & 518.9284 \\
\hline 20 & +10 & -7.78 & 60.5284 \\
\hline 21 & 0 & -17.78 & 315.1284 \\
\hline 22 & +45 & 27.22 & 740.9284 \\
\hline 23 & +30 & 12.22 & 149.3284 \\
\hline 24 & +5 & -12.78 & 163.3284 \\
\hline 25 & +15 & -2.78 & 7.7284 \\
\hline 26 & +30 & 12.22 & $149 \cdot 3284$ \\
\hline 27 & +5 & -12.78 & 7.7284 \\
\hline $\mathrm{N}=27$ & $\sum \mathrm{d}=480$ & & $\begin{array}{c}\sum \mathrm{X}^{2} \mathrm{~d}=5311 \\
0668\end{array}$ \\
\hline
\end{tabular}

Tabel 4.8

Cara Menentukan Xd dan $\mathrm{X}^{2} \mathrm{~d}$

$$
\begin{aligned}
\mathrm{Md} & =\frac{\text { Ed }}{\frac{N}{N 80}} \\
& =\frac{48}{27} \\
& =17.18
\end{aligned}
$$

Tes Signifikansi Untuk Desain 2 adalah:

$$
\begin{aligned}
& \mathrm{T}=\frac{\mathrm{M} d}{\sqrt{\frac{E K^{2} d}{\mathrm{~N}(\mathrm{~N}-1)}}} \\
& =\frac{17.78}{\sqrt{\frac{5311.0668}{27(27-1)}}} \\
& \sqrt{27(27} \\
& =\frac{\sqrt{\frac{5311.0662}{27(26)}}}{\sqrt{17.069}} \\
& \begin{array}{c}
27(26) \\
17.78
\end{array} \\
& =\frac{17.78}{\sqrt{\frac{5311.0662}{702}}} \\
& =\frac{17.78}{\sqrt{7.56}} \\
& =\frac{17.78}{2.74}=6.48
\end{aligned}
$$

Sebelum peneliti menetapkan apakah hipotesis itu diterima atau ditolak, maka terlebih dahulu akan ditentukan derajat kebenarannya. Derajat kebenaran dapat ditentukan denganrumus $\mathrm{db}=\mathrm{N}-1=27-1=26$ dengan taraf signifikasi5\%, maka diperoleh bilangan dalamt-tabel sebesar $=1.706$.

Hal ini berarti hipotesis yang berbunyi "ada pengaruh penerapan model pembelajaran kontekstual berbasis modeling untuk meningkatkanaktivitas dan hasil belajar siswa pada mata pelajaran PKn kelas VII.1 SMP Negeri 3 Mataram,Tahun Pelajaran 2012/2013, diterima.

Dari hasil hitung data di atas dapat ditarik hasil analisa data seperti tercantum pada tabel berikut:
Tabel 4.11

Hasil Analisa Data Untuk Memperoleh Nilai t.

\begin{tabular}{|c|l|l|l|l|}
\hline X1 & X2 & $\begin{array}{l}\text { T- } \\
\text { Hitung }\end{array}$ & $\begin{array}{l}\text { Taraf } \\
\text { Signifikan }\end{array}$ & $\begin{array}{l}\text { T- } \\
\text { Tabel }\end{array}$ \\
\hline 1740 & 2.220 & 6.489 & $5 \%$ & 1.706 \\
\hline
\end{tabular}

Dari hasil analisa data diperoleh nilai t-hitung = 6,48 sedangkant-tabel pada taraf signifikasi $5 \%$ adalah 1,706. Dengan memperhatikan nilai t tersebut di atas, maka dapat dikatakan bahwa nilai t-hitung lebih besar dari pada t-tabel atau dapat dituliskan t-hitung $=6.48>$ t-tabel $=1.706$, ini berarti ada pengaruh yang signifikan terhadap Penerapan Model Pembelajaran Kontekstual berbasis modelinguntuk Meningkatkan Aktivitas dan Hasil Belajar Siswa Kelas VII.1 SMP Negeri 3 Mataram, Tahun Pelajaran 2012/2013.

Ketuntasan belajar siswa dalam tes awal sebelum menggunakan model pembelajaran kontekstualberbasis modeling dan tes akhir setelah penerapan model pembelajaran kontekstual berbasis modeling yaitu ketuntasan belajar siswa secara klasikal sebelum menggunakan model kontekstual berbasis modeling adalah sebesar $44.44 \%$ sedangkan hasil belajar siswa setelah menggunakan model kontekstual berbasis modeling adalah sebesar92.59\%.

\section{PEMBAHASAN}

Berdasarkan hasil analisis data di atas maka dapat dikatakan bahwa hipotesis alternaif (Ha) yang diajukan dalam penelitian ini "diterima", sehingga dapat ditarik kesimpulan bahwa terdapat pengaruh yang signifikan terhadap penerapanmodel pembelajaran kotekstual berbasis modeling untuk meningkatkan aktivitas dan hasil belajar siswa kelas VII.1 pada mata pelajaran PKn di SMP Negeri 3 Mataram, tahun pelajaran 2012/2013.

Nilai rata-rata hasil belajar siswa yang diperoleh dengan menggunakan model kontektual berbasis modelingsebesar82.22 lebih tinggi dari nilai rata-rata hasil belajar siswa sebelum meggunakan model pembelajaran kotekstual berbasis modelingyaitu sebesar 64.44. Hal ini berarti penerapan model pembelajarankontekstual berbasis modeling dapat meningkatkan rata-rata hasil belajar siswa sebesar 17.78.

Selain itu diperoleh perbedaan ketuntasan belajar secara klasikal terjadi pada kedua tes yaitu tes awal (Pre-Test) dan tes akhir (Post-Test) siswa dimana ketuntasan belajar siswa yang menggunakan model pembelajaran kontekstual berbasis modeling sebesar 92.59\% sedangkan pada Pre-Test (sebelum menggunakan model kontekstual berbasis modeling) ketuntasan belajar siswa sebesar $44.44 \%$.

Oleh karena itu pendapat di bawah ini dapat mempertegas tentang ketuntasan pembelajaran:

Ketuntasan pembelajaran dapat dilihat dari segi proses dan dari segi hasil. Dari segi proses pembelajaran dikatakan berhasil dan berkualitas apabila seluruhnya atau setidak-tidaknya sebagian besar $(75 \%)$ peserta didik terlibat secara aktif, baik fisik, mental, maupun sosial dalamproses pembelajaran. Disamping penunjukkan kegiatan belajar yang tinggi, semangat belajar yang besar danrasa percaya pada diri sendiri. Sedangkan dari segi hasil, proses pembelajaran dikatakan berhasilapabila terjadi perubahan perilaku yang positif pada diri peserta didik seluruhnya atau setidak-tidaknya sebagian besar (75\%). Lebih lancar 
proses pembelajaran dikatakan berhasil dan berkualitas apabila masukkan merata, menghasilkanout-put yang banyak dan bermutu tinggi serta sesuai dengan kebutuhan perkembangan masyarakat dan pembangunan (Mulyasa, 2006: 101102).

Penggunaan model pembelajaran kontekstual berbasis modeling dapat meningkatkan aktivitas dalam proses belajar mengajar. Hal ini ditunjukkan pada proses belajar mengajar di kelas dimana setiap siswa menemukan ide-ide pokok yang dikembangkan dalam bahan bacaan, dari bahan bacaan tersebut siswa merumuskan pertanyaan-pertanyaan dari bahan bacaan yang belum dimengerti yang kemudian siswa mencoba untuk memahami materi yang dipelajari dengan pengetahuan yang sudah dimiliki sebelumnya dan dilanjutkan dengan tanya jawab (diskusi) dengan temanteman atau guru kemudian diakhiri dengan siswa membuat rangkuman atau merumuskan intisari dari bahan yang telah dibaca.

Dengan model pembelajaran kontekstual berbasis modeling memungkinkan siswa memanfaatkan setiap peluang untuk belajar. Proses belajar siswa tidak hanya berfokus dalam kelas, karena dengan model pembelajaran kontekstual berbasis modeling mudah digunakan sehingga siswa mempunyai kesempatan lebih besar untuk belajar di luar kelas terutama di rumah.

Dari hasil di atas, guru PKn diharapkan menerapkan model pembelajaran dengan menggunakan model kontektual berbasis modeling dalam proses belajar mengajar, karena relatif mudah dan sangat simpel dalam pelaksanaannya.

\section{SIMPULAN DAN SARAN}

\section{KESIMPULAN}

Berdasarkan hasil penelitian yang dilakukan di kelas VII. 1 SMP Negeri 3 Mataram dapat ditarik kesimpulan sebagai berikut:

a. Penerapan model pembelajaran kontekstual berbasis modeling dapat meningkatkan aktivitas dan hasil belajar siswa kelas VII.1 pada mata pelajaran PKn di SMP Negeri 3 Mataram, Tahun Pelajaran 2012/2013. Peningkatan ini dapat dilihat dari hasil tes siswa sebelum dan sesudah menggunakan model pembelajaran berbasis modeling.Peningkatan hasil belajar ini terlihat dari peningkatan nilai rata-rata siswa yang diperoleh dengan menggunakan model pembelajaran kontektual berbasis modeling sebesar 82.22 dan nilai rata-rata siswa yang diperoleh dengan tidak menggunakan model pembelajaran beerbasis modeling sebesar 64.44. terbukti dari adanya peningkatan belajar siswa sebesar 17.78.

b. Penerapan teknik pembelajaran kontekstual berbasis modeling dapat meningkatkan aktivitas dan hasil belajar siswa kelas VII.1 SMP Negeri 3 Mataram Tahun Pelajaran 2012/2013. Hal ini ditunjukkan dengan hasil post-test dengan nilai 92.59 sedangkan hasil Pre-Test dengan nilai 44.44. dengan melihat hasil Post-Test dan Pre-Test bahwa penerapan model pembelajaran kontekstual berbasis modeling dapat meningkatkan hasil belajar dan aktivitas belajar siswa.
Dari uraian di atas, maka dapat dikatakan hipotesis (Ha) berbunyi bahwa model pembelajaran kontekstual berbasis modeling dapat meningkatkanaktivitas dan hasil belajar siswa kelas VII.1 pada Mata Pelajaran PKn Tahun Pelajaran 2012/2013, "diterima".

\section{SARAN}

\section{a) Bagi Guru}

1) Guru disarankan tidak hanya fokus pada penggunaan metode ceramah, tetapi harus membuat dan merangsang metode yang dapat menciptakan suasana belajar yang melibatkan peran aktif siswa.

2) Guru disarankan menanamkan dan membina sikap demokratis diantara siswa agar siswa dapat dengan mudah bekerja sama dengan teman-temannya terutama dalam memecahkan masalah-masalah yang ditemui siswa dalam belajar.

\section{b) Bagi Siswa}

1) Siswa hendaknya harus bisa menghargai perbedaan yang ada dalam kelas baik itu perbedaan pendapat ide, gagasan, dan pemikiran serta perbedaan-perbedaan yang ada baik itu di kelompok maupun di kelas secara komprehensif.

2) Siswa hendaknya harus lebih berani dalam bertanya, maupun mengungkapkan ide-ide dan pendapat yang lebih cemerlang kepada guru maupun teman-temannya.

\section{c) Bagi Sekolah}

1) Sekolah hendaknya selalu mendorong guru-guru untuk menerapkan model maupun metode yang menerapkan siswa sebagai subyek belajar bukan obyek belajar.

2) Sekolah hendaknya meningkatkan dan menyediakan fasilitas yang memadai guna mempermudah guru dalam menggunakan maupunmenerapkan metode-metode pembelajaran yang bervariasi sehingga dapat meningkatkan mutu sekolah agar dapat bersaing dengan sekolah-sekolah lain yang lebih diunggulkan.

\section{DAFTAR RUJUKAN}

Arikunto, Suharsimi. 2008. Dasar-Dasar EvaluasiPendidikan. Jakarta: Bumi Aksara. Pendekatan Praktik. Jakarta: Rineka Cipta.

Darsono, Max. 2002. Belajar dan Pembelajaran. Semarang: IKIP Semarang.

Djamarah, S. B. 2010. Strategi Belajar Mengajar. jakarta : PT. Rineka Cipta.

Hamalik Oemar, 2006. Proses Belajar Mengajar. Yogyakarta, PT. Bumi Aksara

--. 2010.Proses Belajar Mengajar. Jakarta:

Bumi Aksara.

Johnson, Elaine B, 2011. Contextual Teaching and Learning. Bandung, Kaifa.

Nasution S, 2006. Berbagai Pendekatan Dalam Proses Belajar Mengajar, Bumi Aksara. Bandung.

Margono, 2009. Metodologi Penelitian Pendidikan. Jakarta. Rineka cipta.

Saeful B, 2002. Pendidikan kewarganegaraan. Universitas Negeri Surabaya. Univercity Press.

Slameto, 2010. Belajar dan Faktor-Faktor Yang Mempengaruhinya. Jakarta: PT. Rineka Cipta. 
50 CIVICUS | Pendidikan Pancasila dan Kewarganegaraan | Vol. 4, No. 2, September 2016, hal 40-50

Sugiyanto, 2010. Model-Model Pembelajaran Inovatif. Surakarta : Yuma Pustaka bekerja sama dengan FKIP UNS.

Sundara, komang. 2012. Diktat kuliah metode penelitian pendidikan. Universitas Muhammadiyah Mataram.

Sanjaya Wina, 2008: 254-255. Strategi Pembelajaran (Berorientasi Standar Pendidikan). Kencana Panda Media Gruop. Jakarta.

Sardiman, 2003. Interaksi Dan Motivasi Belajar Mengajar. Jakarta : Raja Grafindo Persada.

Zulkifli, 2009. Penerapan Pembelajaran Kontekstual Dalam Pengajaran PKn Terhadap Prestasi Belajar Kelas VIII SMPN 4 Bima. UMM. 